\title{
OBITUARY
}

\section{Mr. Percy Dunn}

THE recent death of Mr. Dunn was briefly referred to in our last issue. The son of a north-country parson, Mr. Dunn was born 76 years ago, at Warkworth, Northumberland. Educated at Richmond and Clapham, he entered St. Bartholomew's Hospital and subsequently studied in Paris. He qualified M.R.C.S., in 1876, and took the F.R.C.S. Eng. four years later. For many years he was Ophthalmic Surgeon to the West London Hospital, where he took an active part in organizing the post-graduate medical college of the hospital. He also took a large share in the work of the West London Medico-Chirurgical Society, of which he was, at one time, Secretary and Vice-President.

Apart from professional work of this kind he was recognized as an efficient medical journalist. He edited at one time the FrancoBritish Medical Review; from 1896 to 1904 he edited the West London Medical Journal, and later the Medical Press and Circular, and the Bulletin of the Fellowship of Medicine.

Some of our earlier volumes are enriched by contributions from his pen to the Masters of British Ophthalmology series, notably, the Memoirs of James Ware and Benjamin Travers..

\section{NOTES}

Death

Appointments

Oxford

Ophthalmological Congress

have been made.

As we go to Press we regret to record the death of Mr. Edward William Wood White, M.D., of Birmingham, in his $77_{\text {th }}$ year.

Mr. L. H. Savin and Mr. Arnold Sorsby have been elected Assistant Surgeons to the Royal Eye Hospital.

The Twenty-first Annual Meeting will be held at Keble College, on July 8 to July 11. The following arrangements

July 9. Symposium on "The Diagnosis of Intra-cranial New' Growths." "The openers will be Mr. Leslie Paton, from the 